\title{
Cattle grazing has varying impacts on stream-channel erosion in oak woodlands
}

\begin{abstract}
Melvin R. George
Royce E. Larsen

Neil K. McDougald

Kenneth W. Tate

John D. Gerlach, Jr.

Kenneth O. Fulgham

$\nabla$

We conducted a 5-year study on the impact of grazing on streamchannel bare ground and erosion, and a 3-year study of cattle-trail erosion on intermittent stream channels draining grazed oak-woodland watersheds. While the concentration of cattle along stream banks during the dry season resulted in a significant increase in bare ground, we were unable to detect streambank erosion resulting from any of the grazing treatments applied. However, we did find that cattle trails are an important mode of sediment transport into stream channels. While cattle trails are common on grazed rangeland, excessive trailing often indicates that stock watering points are too far apart.
\end{abstract}

M ost of California's surface water flows through the state's 16 million acres (6.4 million hectares) of annual rangelands in foothills. These foothill rangelands are drained by intermittent streams, which begin to flow following adequate rainfall during the October-toMay rainy season (Lewis et al. 2000). In dry years many intermittent streams in these rangelands do not flow. Sediment is a nonpoint source pollutant of concern in these surface waters.

Erosion and resulting sedimentation is a natural process that is often accelerated by human activities such as mining, construction, roads, timber harvest, crop production and livestock grazing. Excessive sedimentation clouds water, which

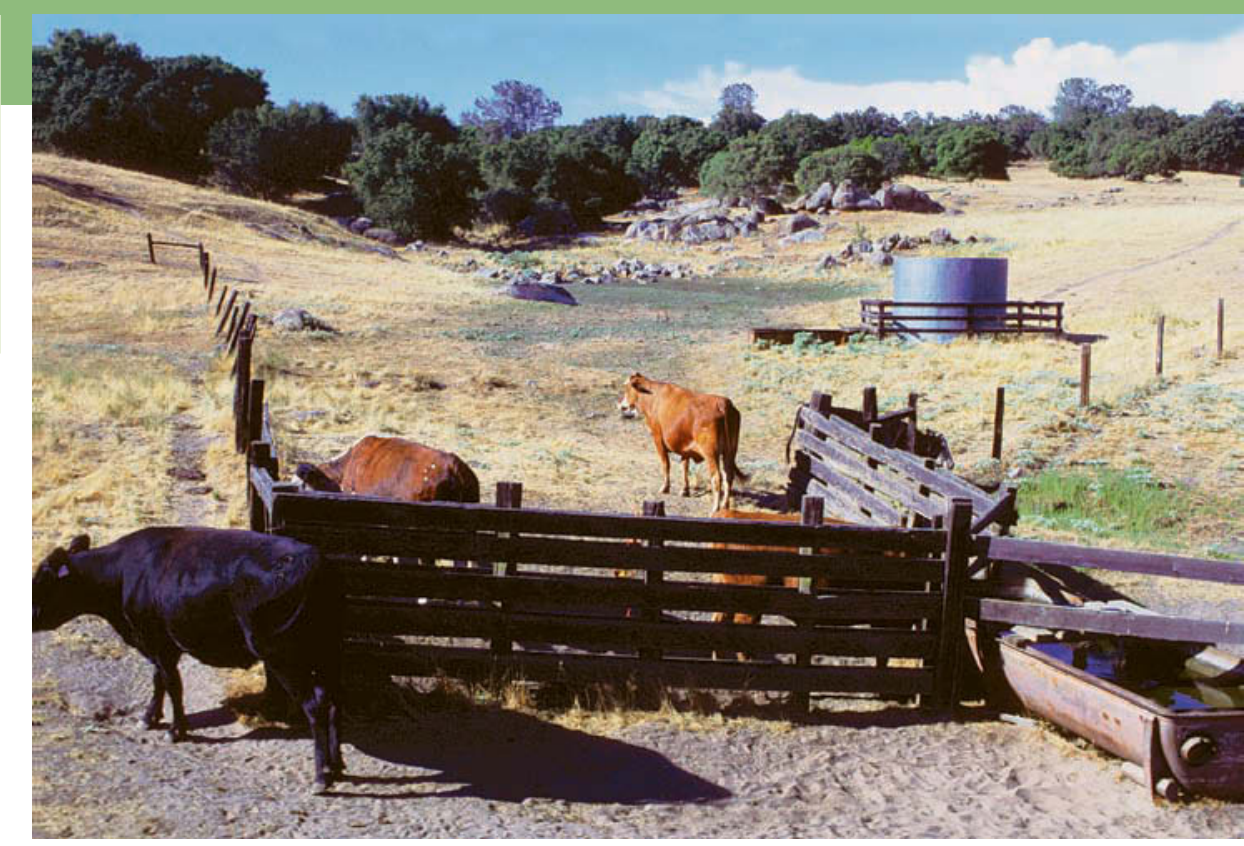

There are 16 million acres of grazed rangeland in California's foothills. Much of the state's water flows through these areas and can be polluted with sediment from livestock grazing. Additional troughs and watering ponds can improve cattle distribution and protect water quality.

reduces the amount of sunlight reaching aquatic plants; covers fish spawning areas and food supplies; and clogs the gills of fish. In addition, other pollutants such as phosphorus, pathogens and heavy metals are often attached to the soil particles and end up in downstream water bodies. Consequently, landowners and managers are planning and implementing erosion-control practices as part of regulatory requirements to reduce sediment loading in coastal streams and rivers (see page 134, 149). Because grazing is the dominant use of foothill rangelands it is frequently implicated as a source of sediment. However, Lewis et al. (2001) found that roads were a larger sediment source on ranches than grazing.

Improper livestock use can increase stream-bank erosion and sedimentation by changing, reducing or eliminating the vegetation that borders streams (Kaufman and Krueger 1984). Several studies have implicated livestock-induced stream-bank erosion, which leads to channel downcutting or widening (Kaufman and Krueger 1984; Hall and Bryant 1995; Sierra Nevada Ecosystem Project 1996).
In 1994, we began to monitor sediment delivery at the bottom of a 342-acre grazed oak-woodland watershed in Madera County. While not continuously grazed, this watershed was grazed several times each year, leaving 600 to 800 pounds of residual dry matter per acre in the fall, which meets UC guidelines (Bartolome et al. 2002).

We found that little sediment was suspended in water samples collected near the bottom of the watershed. On further investigation we found that most sediment moved along the bottom of the channel as bedload during storm runoff, increasing with flow and settling in low-gradient reaches of the stream channel (George et al. 2002). At this site, grazing management generally maintained adequate residual dry matter (Bartolome et al. 2002) on hill slopes; in addition, earlier studies by the U.S. Department of Agriculture's Natural Resources Conservation Service (USDA/NRCS) had documented little overland flow and resulting surface erosion. Therefore, we suspected that the source of most of the bedload sediment was the stream channel and the adja- 


\section{Livestock grazing impacts, such as stream-channel erosion and impaired water quality, can often be addressed with manage- ment practices that alter livestock distribution on the landscape.}

cent variable-source area that merges with the stream channel. We initiated two studies to determine the influence of grazing cattle on erosion in or near stream channels. The stream-channel study documented changes in streamchannel groundcover and stream-bank erosion due to different seasons and intensities of grazing. The cattle-trail study compared sediment movement on cattle trails and adjacent vegetated surfaces on the slopes of the variablesource area that merges with the stream channel. The purpose was to determine if cattle grazing and trampling contributed to the bedload sediment associated with intermittent stream channels in the central Sierra Nevada foothills.

\section{San Joaquin Experimental Range}

These studies were conducted on the San Joaquin Experimental Range (SJER) in Madera County in oak woodlands, which are dominated by coarse-loamy granitic soils of the Ahwahnee series (fig. 1). Numerous intermittent stream

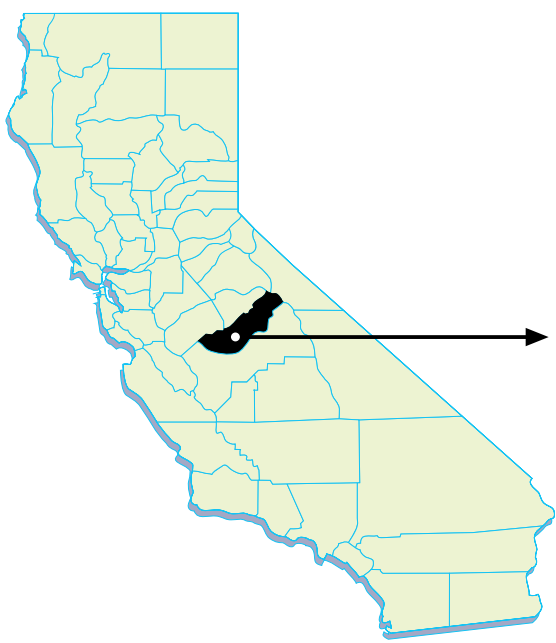
No grazing
Wet season, moderate
Wet season, concentrated
Dry season, moderate
Dry season, concentrated

channels, most of which are tributaries to Cottonwood Creek, dissect the station. Cottonwood Creek is a fourthorder stream that drains into the San Joaquin River just below Friant Dam. During this study, stream flow began in early January following 11 to 14 inches (270 to 360 centimeters) of rainfall from October to December. While granite rocks, oak trees and other woody vegetation provide some stability, the majority of the stream banks are vegetated by shallow-rooted annual grasses and forbs. The stream bottoms are predominantly sand with some granitic cobble, rock and boulders. The channels are 2 to 10 feet wide, 1 to 3.3 feet deep and bedrock-controlled in many reaches. Three intermittent tributaries to Cottonwood Creek were selected for study at SJER. The study reaches (stream segments) are low-gradient with less than $2 \%$ slope and are Rosgen Class B5 (Rosgen 1996). Stream channels 1, 2 and 3 are 1 to 2 miles apart and at an elevation of 900 to 1,348 feet.

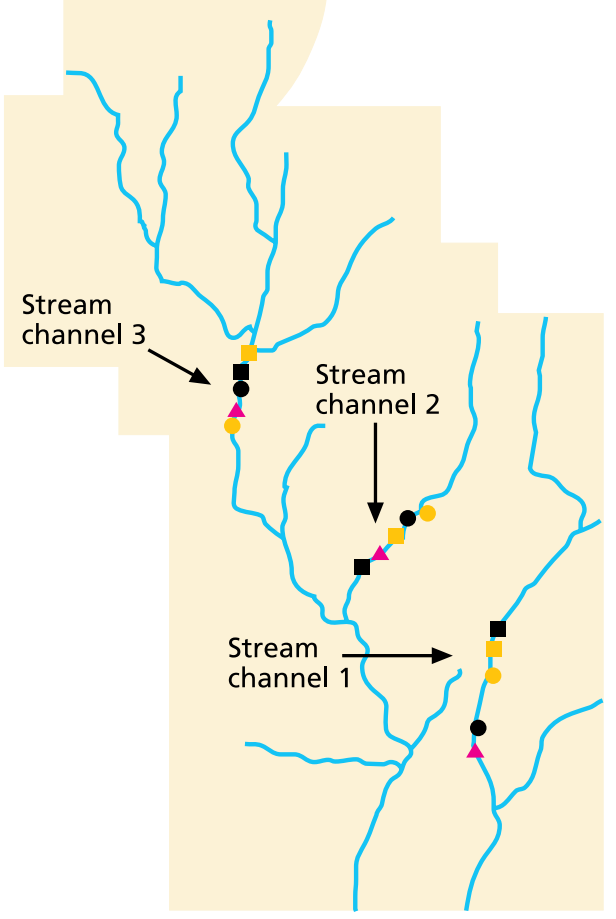

Fig. 1. Location of Madera County study site, and treatments along stream channels at the U.S. Forest Service San Joaquin Experimental Range. 


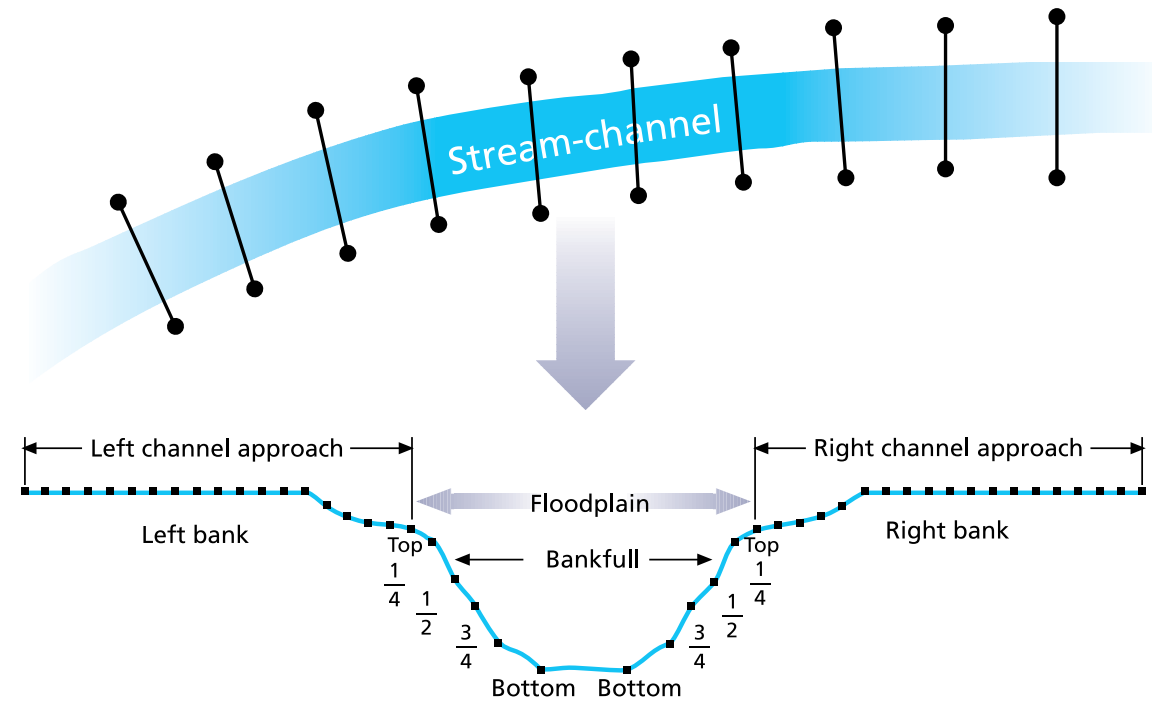

Fig. 2. Diagram of 10 stream-channel cross-section transects.

\section{Grazing impacts on stream channels}

Maintaining adequate vegetative groundcover is the first defense against soil erosion. Thus, decreasing groundcover or increasing bare ground is an indication of increasing risk of erosion. Increasing stream-channel width and depth are indicators of streamchannel erosion. The objective of our study on stream channels was to determine changes in bare ground along the channel banks and changes in channel width and depth in response to two seasons (wet and dry) and three grazing intensities (no grazing, moderate and concentrated).

Grazing treatments. Five grazing treatments were applied to five randomly selected 1-acre pastures established for a 5-year study along each of three intermittent streams (fig. 1). The treatments were:

- No grazing.

- Wet season, moderate grazing (stubble height $=2$ to 3 inches).

- Wet season, concentrated grazing (stubble height $<2$ inches).

- Dry season, moderate grazing (stubble height $=2$ to 3 inches).

- Dry season, concentrated grazing (stubble height $<2$ inches).

The concentrated grazing treatments were designed to apply the extremely heavy use often associated with a feed or watering site. Each grazing treatment was applied to the same pastures during 4 consecutive years.

Dry-season grazing treatments were applied between July 1 and Oct. 1, a period of little or no rainfall. Wet-season treatments were applied while the soil was moist and maintained until the end of the growing season. Typically, the wet season begins in late October or early November and ends by May 1 . This period includes the slow winter growth period and all of the rapid spring growth period of the growing season (George et al. 2001). The moderate and concentrated grazing treatments were stocked at about 1.7 acre per animal unit month. Cooked molasses protein supplements and mineral blocks were placed along the stream banks in the pastures treated with the concentrated grazing treatments and additional animals were added to achieve the target stubble height associated with feeding and watering sites. For the concentrated grazing treatments, instantaneous stock densities equivalent to 100 cows per acre were occasionally achieved but not maintained within the corridor delineated by the cross-section transects.

Measuring stream-channel erosion. Stream-channel measurements were recorded during the first week of June at the beginning of the dry season starting with a baseline year in June 1994. Channel cross-sections were measured using methods outlined by Bauer and Burton (1993). For each stream reach, 10 permanent cross-section transects, 20 to 30 feet long, were placed perpendicular to the stream channel at a distance of 1 to 1.5 times the channel width apart (fig. 2). The transects were marked with permanent stakes and referenced to a permanent benchmark. Stream-channel elevation was determined every 6 inches (15 centimeters) along the transect using a stretched tape, laser level and stadia rod. For each transect, we measured width at bankfull, distance from the left permanent stake to both right and left bank at bankfull height, depth every 6 inches, and maximum depth. Crosssectional area, channel average depth and width-to-depth ratio were calculated. Pasture averages for each morphological parameter were calculated from the 10 transects in each pasture. Cross-sectional area of the channel was determined using bankfull elevations following the methods of Rosgen (1996). Elevation and position readings of the permanent end-stakes were checked with benchmark elevations each year.

Measuring groundcover. Groundcover was determined using the linepoint transect method (Bonham 1989) along the same transects used to survey elevations for stream-channel morphology (Bauer and Burton 1993). Bare ground was calculated by subtracting the percentage of groundcover from 100 .

To separate cattle impacts on the channel bank from the adjacent floodplain and uplands, the line-point transect was divided into two sections on each side of the channel (fig. 2). The channel bank is the often-steep component of a stream channel extending from the channel bottom to the top of the bank. This section includes the point often defined as "bankfull" (Rosgen 1996). Bare ground was determined at five points along the left and right channel banks: top of bank, bottom of bank, and one-quarter, one-half and threequarters of the distance from the top of the bank to the channel bottom (fig. 2). The stream-channel approach extended 9 feet (270 centimeters) from the top of the bank and included varying portions of the floodplain (Rosgen 1996) and uplands depending on channel morphology along the channel reach. Bare ground was determined from the top of the bank to 3 feet at 6-inch intervals, 

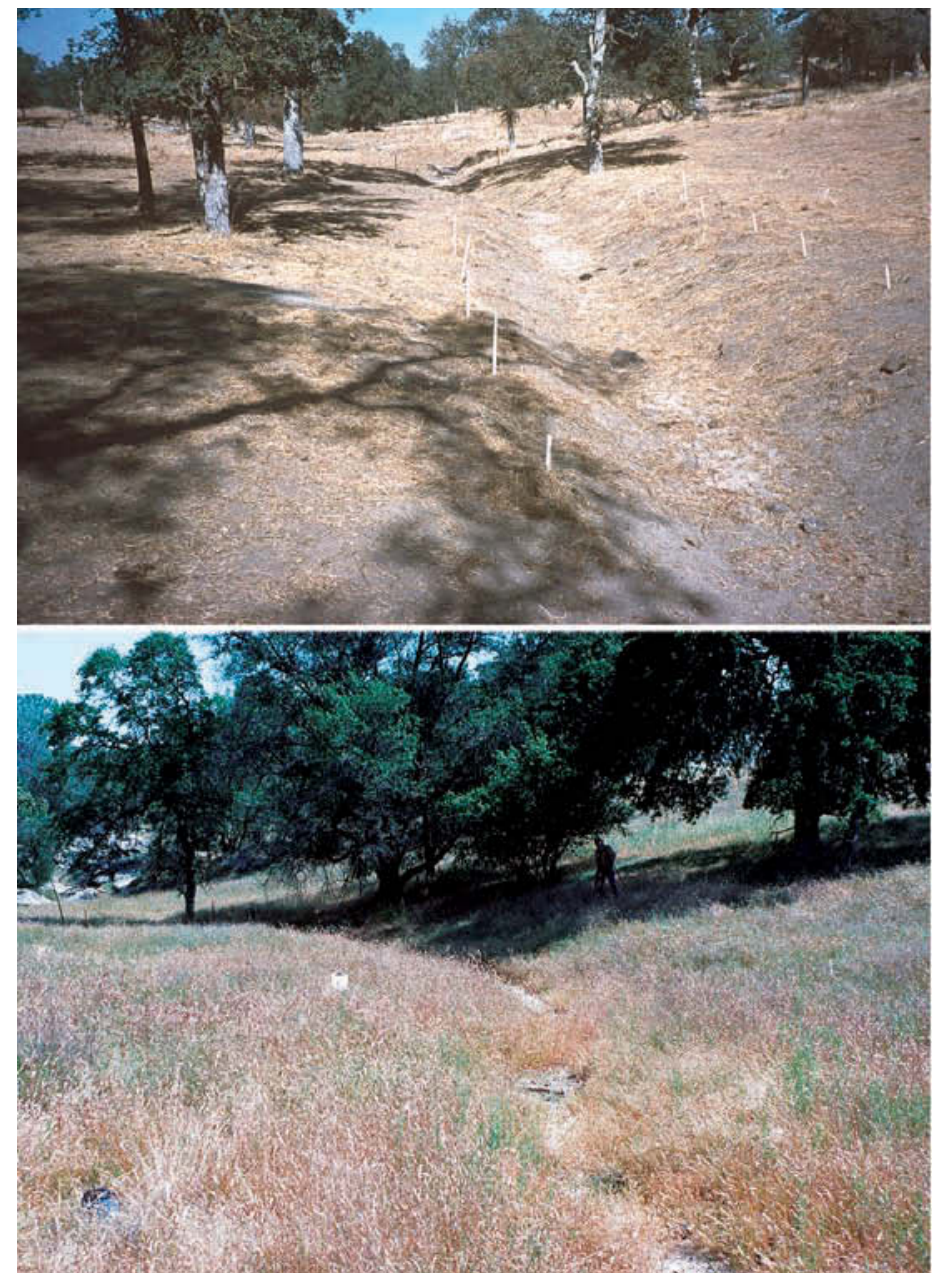

Fall comparison of stream channel in concentrated grazing treatment, upper, and no grazing, lower.
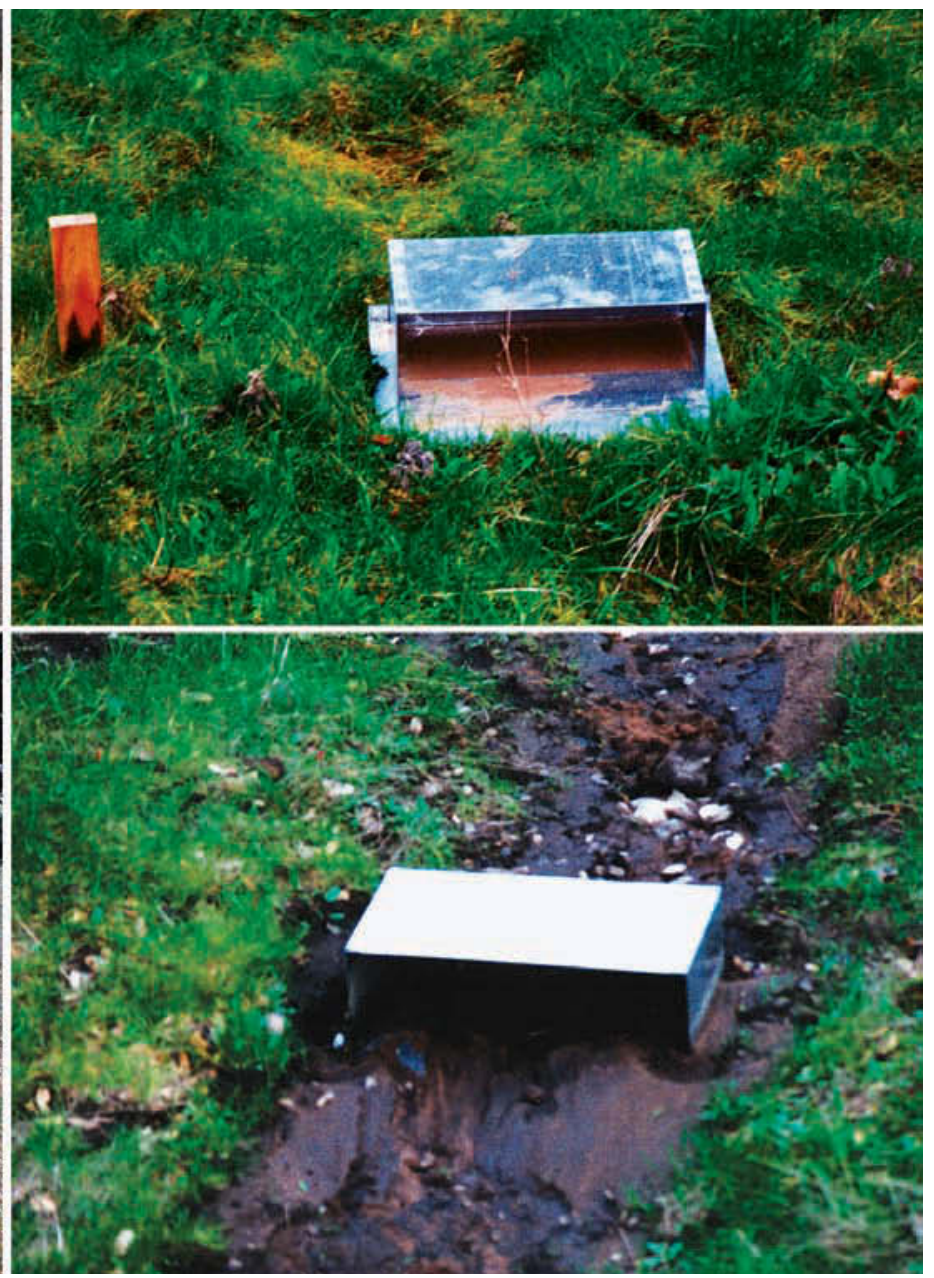

Comparison of sediment trap in a vegetated area, upper, and sediment trap in an adjacent trail, lower. and at 1-foot intervals from 3 to 9 feet along the stream cross-section transect.

\section{Bare ground, channel effects}

There were significant $(P<0.001)$ increases in bare ground on the channel bank and approach due to dry-season concentrated grazing when compared to the ungrazed control (fig. 3). Bare ground for the other grazing treatments was not significantly different from the ungrazed control or the dry-season concentrated treatment. These results indicate that practices causing cattle to congregate near stream channels during the dry season can significantly decrease groundcover, which protects the soil surface from erosion. Because these streams are dry during the summer they are generally not attractive to cattle. Therefore, the intensity of grazing and trampling resulting from the concentrated grazing treatment is unlikely to occur under proper stocking rates and grazing practices.
No significant $(P>0.05)$ stream-bank erosion was detected when each streamchannel measurement (width, distance to right and left bank, maximum depth, mean depth, cross-sectional area or width-to-depth ratio) for each of the five grazing treatments was averaged across all years. Stream-channel depth changed significantly $(P<0.05)$ from year to year, reflecting the seasonal and annual movement of bedload along the stream-channel bottom. The greatest between-year change was from 1996 to 1997 - an above-average rainfall year - resulting in higherthan-normal flow events that scoured bedload sediment from the channel, increasing stream-channel depth.

In their review, Trimble and Mendel (1995) found conflicting reports on the relationship between grazing along stream channels and sediment loss from stream banks. Several of these studies reported that increased channel width was the result of sloughing of undercut banks. The stream-channel banks in this study were not undercut, and could not achieve this form under any grazing scheme due to the sandy soil type and dominance of shallow-rooted annual vegetation.

We observed grazing and trampling along the stream-channel bank by cattle in the treated pastures, yet detected no change in channel width at bankfull. Fine-textured and wet stream-bank soils have been shown to be a factor in vulnerability to erosion (Clary and Webster 1990; Wolman 1959; Hooke 1979; Marlow and Pogacnik 1985; Marlow et al. 1987). The stream-bank soils in our study may be less likely to erode because they are well-drained coarse sands that have a low water-holding capacity. Trimble and Mendel (1995) suggested that watersheds subjected to high-intensity, long-duration storms generating high stream discharges were more vulnerable to stream-bank erosion than watersheds that receive relatively 

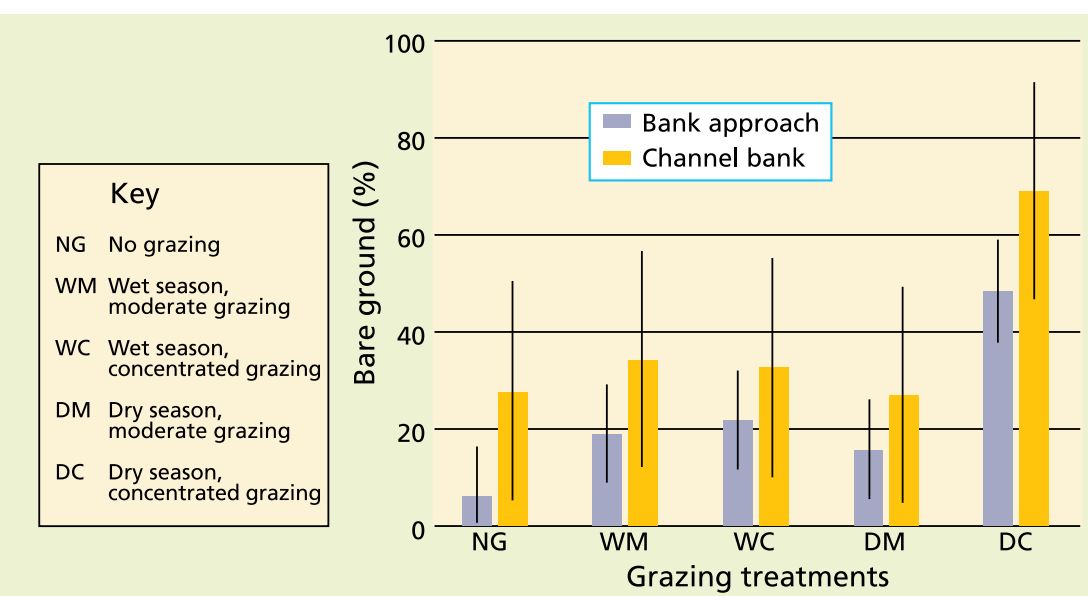

Fig. 3. Comparison of effects of fall treatment on bare ground (\%) for bank approach and channel bank. Bars indicate $95 \%$ confidence level.

equitable flow from snowmelt. During our study one or more high stream discharges occurred each year, lasting for only a few hours during and following a storm. However, such single storm events were not intense or sustained enough to lead to significant erosion. Lack of high-intensity rainfall and runoff early in the rainy season may reduce stream-bank erosion. While intense grazing and trampling can leave unvegetated loose soil at the beginning of the rainy season, low-intensity rainfall, characteristic of the early rainy season, results in germination and seedling establishment that stabilizes grazed and trampled soil surfaces before periods of more intense rainfall begin.

Channel deepening was detected in the control treatments, indicating a loss of bedload sediment from the control reaches. Treatment randomization within each stream (block) resulted in the controls being placed at the lowest or next-to-lowest pasture in the sequence of five pastures along each stream. One might expect channel depth in the controls to become shallower if they were influenced by the delivery of sediment from upstream grazed treatments, but not for the channel to deepen. While there was no significant change in channel width, there was a trend toward channel narrowing that may have resulted in increased stream power, which could have eroded bedload sediment in the control pastures.

Another interpretation of the streamchannel study is that the cross-section method frequently recommended for detecting stream-channel erosion is not sensitive enough to detect the scale of erosion induced by the activity of grazing cattle. Furthermore, erosion resulting from episodic high-flow events may mask grazing-induced erosion. More refined methods of detecting erosion and longer term studies of grazed and ungrazed stream reaches may be the only means of separating grazinginduced erosion from other sources (such as natural and rodent-caused erosion, and roads).

In summary, the risk of grazinginduced stream-bank erosion in the granitic soils of the southern Sierra Nevada foothills is low because: (1) stream banks are not vertical, lowering the risk of bank undercutting and eventual sloughing; (2) the soils lack the fine texture and high water-holding capacity often associated with streambank erosion; (3) these southern Sierra Nevada foothills are not subject to longduration, high-intensity storms; and (4) bare soil surfaces at the beginning of the rainy season are stabilized by newly established seedlings before periods of intense rainfall begin.

\section{Sediment and cattle trails}

During the 1997, 1998 and 1999 water years, sediment traps (Wells and Wohlgemuth 1987) were placed in pairs at several locations along stream channel 2 (fig. 1) that drains the research watershed at the San Joaquin Experimental Range. Traps were sheet-metal boxes open on one side to catch sediment. One of each pair of traps was placed in

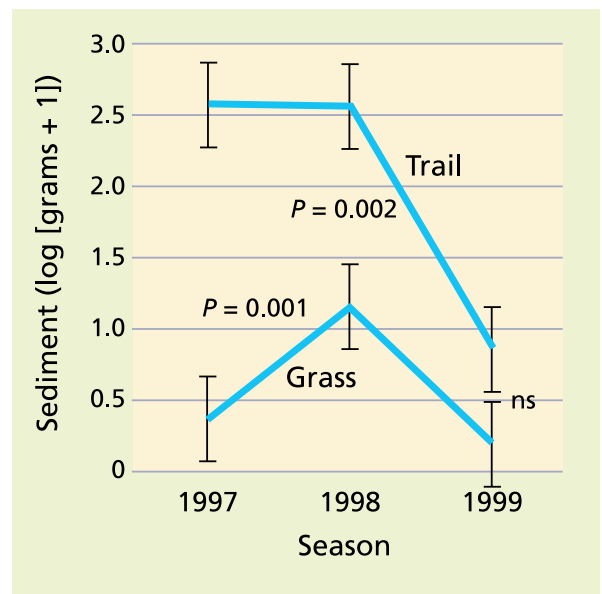

Fig. 4. Comparison of sediment from trails and adjacent grass-covered surfaces for three water years.

a cattle trail near the point where the trail crosses the stream channel. The second sediment trap of each pair was placed in well-vegetated areas of similar slope and slope-length adjacent to the trap in the trail. Throughout the rainy season the sediment traps were emptied as needed during and following storms. Sediment samples were dried and weighed. ANOVA was used to separate treatment and year differences.

Sediment transport was significantly greater in cattle trails than in vegetated areas in the rainfall years ending in 1997 and 1998 (fig. 4). There was no significant difference in 1999. In 1997 and 1998 there was sufficient rainfall to generate measurable runoff, and the intermittent streams began flowing in January of those two rainfall years. Rainfall in 1999 was low, resulting in little runoff and sediment movement in cattle trails. While cattle-trail crossings affect a very small total of the channel length within the watershed, the results of this study suggest that trails can be an important, management-caused conduit of sediment from the variable-source area to the stream channel. Following a major runoff event, we observed diversion of intermittent stream-channel flow into a cattle trail forming a new channel.

Cattle prefer to travel along established trails. In steep terrain, trails provide routes from water sources to preferred foraging sites. Trailing increases as the distance between foraging sites and water sources increases. In steep terrain, one trail may cross 


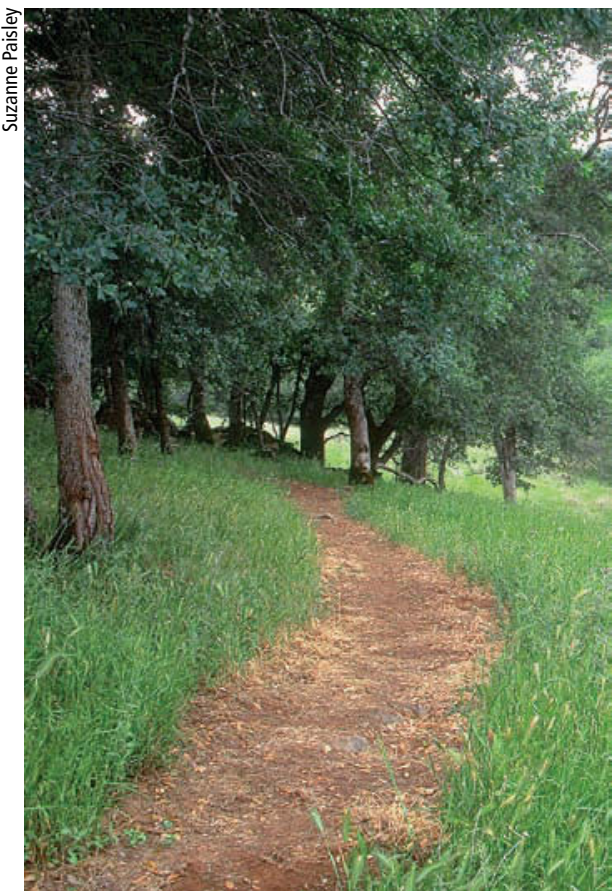

Cattle trails can aid the flow of sediment into streams. By reducing the distance between foraging and watering sites, the formation of cattle trails can be reduced.

several stream channels. Several trails are common in the steep terrain of foothill rangelands, resulting in many trail crossings of each stream channel. Regular trampling by livestock keeps these trails devoid of vegetation throughout the year and reduces the infiltration rate, resulting in increased surface runoff along trails, especially along the downhill approach to stream crossings. During the dry season cattle trampling loosens surface soil, providing a ready source of sediment during the rainy season. The trails become a conduit for surface runoff and a source of sediment.

\section{Reducing stream-channel impacts}

To limit cattle impacts on stream channels, especially on public lands, mitigations such as reduced stocking rates, grazing lease termination, and fencing of streams and riparian areas have frequently been implemented. These practices can devastate the economic viability of range livestock enterprises, reducing their competitive ability and adversely affecting the economies of rural communities. Furthermore, livestock exclusion limits our ability to use grazing to manage wildlife habitat, fire fuel loads and weed infestations. Livestock grazing impacts, such as stream-channel erosion and impaired water quality, can often be addressed with management practices that alter livestock distribution on the landscape. While lease termination and fencing are certain methods of reducing livestock impacts on stream channels and water quality, less restrictive management changes such as strategic placement of water sources and supplemental feeding sites away from critical areas have been shown to reduce livestock grazing impacts (Frost et al. 1989).

Trailing is reduced when the distance between foraging sites and water sources is reduced. Adequate stock-water development can lead to improved control of cattle distribution. Strategic placement of fencing may also reduce trailing. Sediment and other livestock-generated, nonpoint source pollution sources could be substantially reduced with increased water sources on foothill ranches. These rangeland improvements should receive high priority in the allocation of agency conservation and pollution-control funding.

Researchers at UC Davis, USDA and other Western universities are currently studying the effectiveness of traditional distribution practices for attracting livestock away from environmentally critical areas or into areas to be grazed for weed control. The results of these studies will be used to fine-tune our knowledge of how livestock use Western landscapes and to improve our ability to predict the best placement of stock water and supplement sites.

\section{M.R. George is Extension Rangeland} Management Specialist, Department of Agronomy and Range Science, UC Davis; R.E. Larsen is Watershed Advisor, UC Cooperative Extension (UCCE), Paso Robles; N.K. McDougald is Livestock, Range and Natural Resources Advisor, UCCE Madera; K.W. Tate is Extension Rangeland Watershed Specialist and J.D. Gerlach, Jr., is Post-Doctoral Researcher, Department of Agronomy and Range Science, UC Davis; and K.O. Fulgham is Professor of Range Management, Humboldt State University, Arcata. This project was funded by the U.S. Environmental Protection Agency.

\section{References}

Bartolome JW, Frost WE, McDougald NK, Connor JM. 2002. Guidelines for Residual Dry Matter (RDM) Management on Coastal and Foothill Annual Rangelands in California. UC DANR Pub 8092. Oakland, CA. 8 p.

Bauer SB, Burton TA. 1993. Monitoring Protocols to Evaluate Water Quality Effects of Grazing Management on Western Rangeland Streams. EPA 910/R-93-017. US Environmental Protection Agency, Washington, DC. $179 \mathrm{p}$.

Bonham CD. 1989. Measurements for Terrestrial Vegetation. New York: J Wiley. 338 p.

Clary WP, Webster BF. 1990. Recommended riparian grazing practices. Proc $X X I$ Int Erosion Control Assoc. Washington, DC. p 75-81.

Frost WE, McDougald NK, Clawson WJ. 1989. Supplemental feeding location in riparian areas of the south Sierra Foothills of California. Proc Western Section, Amer Soc Animal Sci. p 73-5.

George MR, Bartolome JW, McDougald NK, et al. 2001. Annual Range Forage Production. UC DANR Pub 8018. Oakland, CA. 9 p. George MR, McDougald NK, Tate KW, Larsen R. 2002. Sediment Dynamics and Sources in a Grazed Hardwood Rangeland Watershed. USDA Forest Service Gen Tech Rep PSW-GTR-184. p 65-73.

Hall FC, Bryant L. 1995. Herbaceous Stubble Height as a Warning of Impending Cattle Grazing Damage to Riparian Areas. USDA Forest Service Gen Tech Rep PNW-362. 10 p. Hooke JM. 1979. An analysis of the processes of river bank erosion. J Hydrol 42: 39-62.

Kauffman JB, Krueger WC. 1984. Livestock impacts on riparian ecosystems and streamside management implications: A review. J Range Manage 37:430-8.

Lewis DJ, Singer MJ, Dahlgren RA, Tate KW. 2000. Hydrology in a California oak woodland watershed: A 17-year study. J Hydrol 230:106-17.

Lewis DJ, Tate KW, Harper JM, Price J. 2001. Survey identifies sediment sources in North Coast rangelands. Cal Ag 55(4):32-8.

Marlow CB, Pogacnik TM. 1985. Time of Grazing and Cattle Induced Damage to Stream Banks. USDA Forest Service Gen Tech Rep RM-120. p 270-84.

Marlow CB, Pogacnik TM, Quinsey SD. 1987. Stream bank stability and cattle grazing in southwestern Montana. J Soil Water Conserv 42:291-6.

Rosgen D. 1996. Applied River Morphology. Pagosa Springs, CO: Wildland Hydrology. $290 \mathrm{p}$.

Sierra Nevada Ecosystem Project. 1996. Status of the Sierra Nevada: Assessment Summaries and Management Strategies. Wildland Resources Center Rep No 36. UC Davis. $209 \mathrm{p}$.

Trimble SW, Mendel AC. 1995. The cow as a geomorphic agent - A critical review. Geomorphol 13:233-53.

Wells WG, Wohlgemuth PM. 1987. Sediment Traps for Measuring Onslope Surface Sediment Movement. USDA Forest Service Res Note PSW-393.

Wolman MG. 1959. Factors influencing erosion of a cohesive river bank. Amer J Sci 257:204-16. 